\title{
AN ANALYSIS OF TEST TAKER'S ERROR ON STRUCTURE AND WRITTEN EXPRESSION OF TOEFL TEST AT JLC (JIMS LANGUAGE COURSE)
}

\author{
Aa Qonaatun ${ }^{1}$ \\ Universitas Banten Jaya \\ Serang,Indonesia \\ aaqonaatun@unbaja.ac.id
}

\begin{abstract}
The objective of the research are to find out "Which area do the test takers make error in Structure and Written Expression of the TOEFL Test", and to find out "The describing of the test takers' error of TOEFL test at JLC", the writer conducted the research at JIMS Language Course. The populations of this research is TOEFL test takers at JLC, which consist of 30 participants from population grand total, the methodology used by the writer is content analysis and descriptive qualitative, which will find out about which area do the test takers make error in structure and written expression of the TOEFL test and to find out the describing of the test takers' error of TOEFL test at JLC. The data is collected by analyzes the error of participants' test. The test is structure and written expression, the data is analyzed by using the table of relative frequency. The result shows that the TOEFL test-takers at JLC still have poor ability in structure and written expression or could be said that the result of the research is poor. The Instructor explains structure and written expression clearly and then gave them a lot of exercise to make them understand.
\end{abstract}

Key words: TOEFL, test takers, error, structure, written expression. 


\section{INTRODUCTION}

Language is very important for human beings. It is the most principal means used by human beings to communicate with one to another. People use the language to express their emotions and thoughts, and to solve their problems. Without language, people have a lot of limitations and problems to run their life in this world. By studying a language, we know what the people say, what their aims and what they express

In every academy, people always involve themselves in taking language test. TOEFL is one of the chosen English tests. English language institution is one of the places conducting this kind of test. TOEFL stands for Test of English

as Foreign Language. TOEFL may facilitate students of university to get education experiences abroad because TOEFL is one of the international standardized tests. In general, TOEFL sustains the student's capability in Listening Comprehension, Structure and Written Expression, Vocabulary and Reading Comprehension. Because a significant standard value of students' who take TOEFL test is worth using when they study abroad, many academic people take the test of TOEFL. Besides, an excellent score on TOEFL also indicates a high-quality of English Proficiency of those who use their English in day to day basis.

According to Bloom et. al (1999: 1), evaluation or test, as we see it, is the systematic collection of evidence to determine whether in fact certain changes are taking place in the learner, as well as to determine the amount or degree of change in individual student. From the statement of Bloom, test is important to know whether or not changes to the students can measure the ability of the students, and the students judge the current situation either as successful little or no change at all, or successfulness.

There is a quotation from Merhen and Leman (1984: 8) 'to teach without testing is unthinkable'. This quotation shows us that there is a close connection between teaching and test. 
Measurement is the first step to teaching. Without measurement will not be possible. Without test, there will be no happen feedback. Without feedback we shall not know well about the students achievements. Without fixed learning-system, there will be no knowledge about achievement of the students. By giving the test, teacher can alert feedback of all his or her instructional program students' achievement on what he or she has taught, the process of delivering the materials.

When the students do the test she or he makes error in her or his test. According to Dullay (1982:138) 'errors are flawed slide of learners' speech or writing. Error is found in writing and speaking that cannot be avoided by the students. But it is not only in writing and speaking as language skill but also in vocabulary as language component. A learner's error provides evidence to us that the teacher must have strategies and do something to avoid them to make error again. The strategies that can prevent the student from making error are error analysis. Error analysis is the study of learner's error.

Meanwhile, according to Cronbach (1984: 1), defines test as a "Systematic procedure for observing a person's behavior and describing it with the aid of a numerical scale or a category system".

By using error analysis the teacher tries to identify, to describe and to explain the errors made by the students in the test. It can help the teacher to minimize the student's error in their learning.

Here the $w$ is interested in analyzing error on Structure and Written Expression of TOEFL test that is given to the students, because error analysis can supply the information on which to base decision concerning TOEFL score.

\section{Method}

According to Jeremy Harmer (2001: 78) a method is the practical realization of an approach. A research in problem that is accurate. This research just tries to describe the things that concern with certain 
condition. In other word, the writer uses a content analysis and descriptive qualitative research for this work, which tries to analyze TOEFL structure and written expression of test takers at JLC.

The technique of data collecting that will be done by writer is test results. The writer collects, corrects and analyzes the error of the participants' test result.

The technique of data analysis used in this research is content analysis technique (percentage), which is described in the table percentage. In this table percentage the writer uses the formula:

$\mathrm{P}=\mathrm{F} / \mathrm{N} \times 100 \%$

The meaning is:

$\mathrm{P} \quad=$ Percentage

$\mathrm{F} \quad=$ Frequency

$\mathrm{N} \quad=$ Number of sample which is observed

$100=$ Permanent number

\section{Data Analysis}

The writer took the answer sheets to get the data and the work sheet to analyze. The test covers 11 problems with Noun, 11 problems with Verb, 5 problems with Conjunction, 2 problems with Passive, 2 problems with Pronoun, 2 problems with Adverb and 7 problems with Adjective.

Table 1

Structure and Written expression and each item

\begin{tabular}{|c|c|c|}
\hline No & $\begin{array}{c}\text { Problem } \\
\text { with }\end{array}$ & $\begin{array}{c}\text { Number of } \\
\text { item }\end{array}$ \\
\hline 1 & Noun & $\begin{array}{l}1,2,6,7,10, \\
11,17,19,24, \\
32,37\end{array}$ \\
\hline 2 & Verb & $\begin{array}{l}4,8,12,16,18, \\
22,29,31,34, \\
36,38\end{array}$ \\
\hline 3 & Conjunction & $3,5,13,14,27$ \\
\hline 4 & Passive & 9,26 \\
\hline 5 & Pronoun & 15,23 \\
\hline 6 & Adverb & 20,35 \\
\hline 7 & Adjective & $\begin{array}{l}21,25,28,30, \\
33,39,40\end{array}$ \\
\hline
\end{tabular}

The next step in analyzing the results the test the data analysis will describe the structure and written 
Volume 2 No. 1, Februari 2019

P-ISSN 2623-0062

Universitas Banten Jaya

E-ISSN 2622-9056

expression error that made by

participants as follows:

\begin{tabular}{|c|c|c|c|}
\hline $\begin{array}{c}\text { Problem } \\
\text { with }\end{array}$ & $\begin{array}{c}\text { Item } \\
\text { Numb } \\
\text { er }\end{array}$ & $\begin{array}{c}\text { Frequency } \\
\text { of error }\end{array}$ & Percentage \\
\hline Noun & 1 & 9 & $75 \%$ \\
\hline & 2 & 12 & $100 \%$ \\
\hline & 6 & 4 & $33,3 \%$ \\
\hline & 7 & 11 & $91,6 \%$ \\
\hline & 10 & 11 & $91,6 \%$ \\
\hline & 11 & 11 & $91,6 \%$ \\
\hline & 19 & 10 & $83,3 \%$ \\
\hline & 24 & 9 & $75 \%$ \\
\hline & 32 & 9 & $75 \%$ \\
\hline & 37 & 6 & $50 \%$ \\
\hline & Total & & $\mathbf{7 5 , 7 2 \%}$ \\
\hline
\end{tabular}

Table 2

Frequency error of problem with

Noun

These items are about problem with noun. The table shows us that there are $75,72 \%$ participants who made errors in all items in this problem with noun.

Table 3

Frequency error of problem with verb

\begin{tabular}{|c|c|c|c|}
\hline $\begin{array}{c}\text { Probl } \\
\text { em } \\
\text { with }\end{array}$ & $\begin{array}{c}\text { Item } \\
\text { num } \\
\text { ber }\end{array}$ & $\begin{array}{c}\text { Freque } \\
\text { ncy of } \\
\text { error }\end{array}$ & $\begin{array}{c}\text { Percen } \\
\text { tage }\end{array}$ \\
\hline Verb & 4 & 12 & $100 \%$ \\
\hline & 8 & 2 & $16,6 \%$ \\
\hline & 12 & 10 & $83,3 \%$ \\
\hline & 16 & 11 & $91,6 \%$ \\
\hline & 22 & 10 & $93,3 \%$ \\
\hline & 29 & 6 & $50 \%$ \\
\hline & 31 & 11 & $91,6 \%$ \\
\hline & 34 & 10 & $83,3 \%$ \\
\hline & 36 & 11 & $91,6 \%$ \\
\hline & 38 & 7 & $58,3 \%$ \\
\hline & & & $\mathbf{7 6 , 4 7}$ \\
$\mathbf{\%}$ & & \\
\hline
\end{tabular}

The table above that from all items is $76,47 \%$ participants who made errors in this area describes it. 
Table 4

Frequency error of problem with

\section{Conjunction}

\begin{tabular}{|c|c|c|c|}
\hline $\begin{array}{l}\text { Proble } \\
\text { m with }\end{array}$ & $\begin{array}{c}\text { Item } \\
\text { num } \\
\text { ber }\end{array}$ & $\begin{array}{c}\text { Frequ } \\
\text { ency } \\
\text { of } \\
\text { error }\end{array}$ & $\begin{array}{c}\text { Percen } \\
\text { tage }\end{array}$ \\
\hline \multirow[t]{5}{*}{$\begin{array}{l}\text { Conjun } \\
\text { ction }\end{array}$} & 3 & 5 & $41,6 \%$ \\
\hline & 5 & 12 & $100 \%$ \\
\hline & 13 & 5 & $41,6 \%$ \\
\hline & 14 & 8 & $66,6 \%$ \\
\hline & 27 & 10 & $83,3 \%$ \\
\hline & \multicolumn{2}{|l|}{ Total } & $\begin{array}{c}66,62 \\
\%\end{array}$ \\
\hline
\end{tabular}

From this table describes the error' participants that there are 5 participants or $41,6 \%$ who made errors in item 3, 12 participants or $100 \%$ who made errors in item 5, 5 participants or $41,6 \%$ who made errors in item 13,8 participants or $66,6 \%$ who made errors in item 14 , and 10 participants or $72,87 \%$ who made errors in item 27. So, the percentage of all items is $66,62 \%$
Table 5

Frequency error of problem with

Passive

\begin{tabular}{|c|c|c|c|}
\hline $\begin{array}{c}\text { Probl } \\
\text { em } \\
\text { with }\end{array}$ & $\begin{array}{c}\text { Item } \\
\text { Num } \\
\text { ber }\end{array}$ & $\begin{array}{c}\text { Frequ } \\
\text { ency of } \\
\text { errors }\end{array}$ & $\begin{array}{c}\text { Percen } \\
\text { tage }\end{array}$ \\
\hline $\begin{array}{c}\text { Passi } \\
\text { ve }\end{array}$ & 9 & 11 & $91,6 \%$ \\
\hline & 26 & 8 & $66,6 \%$ \\
\hline \multicolumn{3}{|c|}{ Total } & $\mathbf{7 9 , 1 \%}$ \\
\hline
\end{tabular}

These items are about passive. From the table above shows us that there are 11 participants or $91,6 \%$ who made errors in item 9 and 8 participants or $66,6 \%$ who made errors in item 26. So, the percentage of all items is $79,1 \%$, it is the highest error from all problem in structure and written expression. 
Table 6

Frequency error of problem with

Pronoun

\begin{tabular}{|c|c|c|c|}
\hline $\begin{array}{c}\text { Probl } \\
\text { em } \\
\text { with }\end{array}$ & $\begin{array}{l}\text { Item } \\
\text { num } \\
\text { ber }\end{array}$ & $\begin{array}{l}\text { Freque } \\
\text { ncy of } \\
\text { error }\end{array}$ & $\begin{array}{c}\text { Percen } \\
\text { tage }\end{array}$ \\
\hline $\begin{array}{c}\text { Prono } \\
\text { un }\end{array}$ & 15 & 11 & $91,6 \%$ \\
\hline & 23 & 4 & $33,3 \%$ \\
\hline \multicolumn{3}{|c|}{ Total } & $\begin{array}{c}62,45 \\
\%\end{array}$ \\
\hline
\end{tabular}

From the table, we can see that the percentage of all error' participants in pronoun is $62,45 \%$. The first item is $91,6 \%$ participants who made errors in item 15. The second item is $33,3 \%$ participants who made error in item 23.

Table 7

Frequency error of problem with

Adverb

\begin{tabular}{|c|c|c|c|}
\hline $\begin{array}{c}\text { Probl } \\
\text { em } \\
\text { with }\end{array}$ & $\begin{array}{c}\text { Item } \\
\text { Num } \\
\text { ber }\end{array}$ & $\begin{array}{c}\text { Frequ } \\
\text { ency of } \\
\text { error }\end{array}$ & $\begin{array}{c}\text { Percen } \\
\text { tage }\end{array}$ \\
\hline $\begin{array}{c}\text { Adve } \\
\text { rb }\end{array}$ & 20 & 12 & $100 \%$ \\
\hline & 35 & 6 & $50 \%$ \\
\hline
\end{tabular}

\section{Total}

$75 \%$

These items are about Adverb, from the table above shows us that there are 12 participants or $100 \%$ who made errors in item 20 and 6 participants or $25 \%$ who made errors in item 35 , so, the percentage of all items is $75 \%$.

Table 8

Frequency error of problem with

Adjective

\begin{tabular}{|c|c|c|c|}
\hline $\begin{array}{c}\text { Probl } \\
\text { em } \\
\text { with }\end{array}$ & $\begin{array}{c}\text { Item } \\
\text { num } \\
\text { ber }\end{array}$ & $\begin{array}{c}\text { Frequ } \\
\text { ency of } \\
\text { error }\end{array}$ & $\begin{array}{c}\text { Percen } \\
\text { tage }\end{array}$ \\
\hline $\begin{array}{c}\text { Adjec } \\
\text { tive }\end{array}$ & 21 & 5 & $41,6 \%$ \\
\hline & 25 & 11 & $91,6 \%$ \\
\hline & 28 & 10 & $83,3 \%$ \\
\hline & 30 & 4 & $33,3 \%$ \\
\hline & 33 & 11 & $91,6 \%$ \\
\hline & 39 & 8 & $66,6 \%$ \\
\hline & 40 & 6 & $50 \%$ \\
\hline & Total & $\mathbf{6 5 , 4 2}$ \\
& & & $\%$ \\
\hline
\end{tabular}

These items are about adjective, there are 5 participants or $41,6 \%$ who made error in item 21 , 
there are 11 participants or $91,6 \%$ who made error in item 25, 10 participants or $83,3 \%$ who made error in item 28,4 participants or $33,3 \%$ who made error in item 30, 11 participants or $91,6 \%$ who made error in item 33 and 8 participants or $66,6 \%$ who made error in item 39 and 6 participants or $50 \%$ who made error in item 40 , so the percentage of all items is $65,42 \%$.

\section{Result}

After classifying the items into area tested and explaining the frequency and percentage of error on each item, the following tables describes the sequence structure and written expression based on the highest percentage of error.

\section{Table 9}

The sequence of structure and written expression

\begin{tabular}{|c|l|c|}
\hline No & Problem with & $\begin{array}{c}\text { Percentage of } \\
\text { error }\end{array}$ \\
\hline 1 & Passive & $79,1 \%$ \\
\hline 2 & Verb & $76,47 \%$ \\
\hline 3 & Noun & $75,72 \%$ \\
\hline 4 & Adverb & $75 \%$ \\
\hline
\end{tabular}

\begin{tabular}{|c|l|c|}
\hline 5 & Conjunction & $66,62 \%$ \\
\hline 6 & Adjective & $65,42 \%$ \\
\hline 7 & Pronoun & $62,45 \%$ \\
\hline
\end{tabular}

The table describes about the structure and written expression errors that the participants have made in some problem the highest percentage of error that made by participants is problem with Passive, there are 79,1\% participants who made errors in this area, the second is Verb, there are $76,47 \%$ participants who made errors in this area. The third is Noun, there are $75,72 \%$ participants who made errors in this area, The fourth is Adverb, there are $75 \%$ participants who made errors in this area. The fifth is Conjunction, there are $66,62 \%$ participants who made errors in this area, The sixth is Adjective, there are $65,42 \%$ participants who made errors in this area, the seventh is Pronoun, there are $62,45 \%$ participants who made errors in this area, finally, the lowest percentage of error' participants is pronoun, there are only $62,45 \%$ participants. 


\section{Conclusion}

Concerning to the result of the previous finding, analyzes and the description and interpretation of the data, the writer concludes that:

TOEFL is stands for Test of English as foreign Language, TOEFL Structure and Written Expression is designed to measure one's capability to recognize language that is appropriate for standard written English.

There are two types of questions in TOEFL Structure and Written Expression, especially on paper and pencil-based TOEFL, namely; incomplete sentence and underline words, the kinds of the TOEFL test are: Paper and pencil based TOEFL, Computer based TOEFL and TOEFL iBT (Internet Based Test)

The Test Takers at JLC are still are extremely poor ability in Structure and Written Expression. So, the result of this study the writer could say as negative result. More over, this result can be see from the data of relative frequency, the writer found that the most errors occur in problem with Passive is $79,1 \%$, Whereas the least errors occur in Structure and Written Expression area is problem with Preposition, the percentage of test takers' error in problem with Pronoun is $62,45 \%$.

By analyzing the participants' error in TOEFL Structure and Written Expression, we can prepare what the best strategies to be used for the participants, so that they cannot make errors anymore.

\section{References}

Daryanto, Evaluasi Pendidikan, Rinekha Cipta: Jakarta, 1999.

Dullay, Heidi, et al, Language Two, New York: Oxford University Press, 1982

Fernandes, H.J.X, Testing and Measurement, National Education Planning, Evaluation and Curriculum Development, Jakarta: October, 1984. 
Volume 2 No. 1, Februari 2019

P-ISSN 2623-0062

Universitas Banten Jaya

E-ISSN 2622-9056

Harmer, Jeremy, The Practice of

English Language Teaching,

$3^{\text {rd }}$ edition, England: Longman, 2001.

Purwanto, Ngalim, Prinsip-prinsip

dan Teknik Evaluasi Mengajar,

Bandung:

Rosda Karya, 1984 